\title{
Phytoplankton community structure responses to urban effluent inputs following Hurricanes Katrina and Rita
}

\author{
James L. Pinckney ${ }^{1, *}$, James L. Wee ${ }^{2}$, Aixin $\mathrm{Hou}^{3}$, Nan D. Walker ${ }^{4}$ \\ ${ }^{1}$ Marine Science Program and Department of Biological Sciences, University of South Carolina, Columbia, \\ South Carolina 29208, USA \\ ${ }^{2}$ Department of Biological Sciences, Loyola University, New Orleans, Louisiana 70118, USA \\ ${ }^{3}$ Department of Environmental Sciences, School of Coast and Environment, Louisiana State University, Baton Rouge, \\ Louisiana 70803, USA \\ ${ }^{4}$ Department of Oceanography and Coastal Sciences, Louisiana State University, Baton Rouge, Louisiana 70803, USA
}

\begin{abstract}
The recent flooding in the city of New Orleans, Louisiana (USA), following Hurricanes Katrina and Rita offered a unique opportunity to observe how ecological processes in Lake Pontchartrain were altered following the large inputs of untreated urban wastewater delivered during pumping operations to de-water the city. The purpose of this study was to quantify the response and recovery of phytoplankton in Lake Pontchartrain following this major environmental pollutant loading event. Weekly to biweekly water samples were collected at 27 locations within a $12 \mathrm{~km}$ radius from a point-source discharge at the 17th Street Canal outfall from15 September to 12 December 2005 (17 to $105 \mathrm{~d}$ after the passage of Hurricane Katrina). High performance liquid chromatography (HPLC) measurements of photosynthetic pigments and ChemTax were used to quantify the relative abundances of diatoms, dinoflagellates, cyanobacteria, euglenophytes, chlorophytes, and cryptophytes. Phytoplankton blooms with a magnitude as high as $42 \mu \mathrm{g}$ chl a $\mathrm{l}^{-1}$ were limited to a $40 \mathrm{~d}$ period following Katrina and were concurrent with de-watering operations for New Orleans. Phytoplankton biomass returned to relatively low, constant levels over much of the study area after active pumping and discharge of the wastewater effluent. Overall, phytoplankton group diversity declined 1 mo after Katrina and remained relatively constant, while group evenness showed little change. Although the relative abundances of algal groups were variable, diatoms constituted over half of the phytoplankton biomass (median: $51 \%$ of total $\mathrm{chl} \mathrm{a}$ ) and were consistently the most abundant group over the study period. Other than a moderate bloom during pumping operations, Hurricanes Katrina and Rita had very little direct prolonged impact on phytoplankton biomass, evenness, and diversity in Lake Pontchartrain.
\end{abstract}

KEY WORDS: HPLC $\cdot$ ChemTax $\cdot$ Diversity $\cdot$ Pollutant $\cdot$ Lake Pontchartrain Resale or republication not permitted without written consent of the publisher

\section{INTRODUCTION}

Understanding the response and recovery of natural systems to unpredictable catastrophic events is a fundamental goal of ecosystems ecology. The recent flooding in New Orleans, Louisiana (USA), following Hurricane Katrina offered a unique opportunity to observe how ecological processes in Lake Pontchartrain, an oligohaline lagoonal estuary, were altered following the large-scale inputs of untreated urban wastewater pumped from the city during de-watering operations.

In aquatic ecosystems, phytoplankton play a major role in regulating pelagic food webs, and the taxonspecific responses to pollutants and contaminants can be substantial (Roelke et al. 1997, Riedel et al. 2003). From the ecosystem perspective, phytoplankton may 
alter $\mathrm{O}_{2}$ dynamics, biogeochemical cycling, and trophic state. Even minor changes in phytoplankton species assemblages could result in significant shifts in the fate of primary productivity (e.g. grazing versus deposition) with subsequent changes in $\mathrm{O}_{2}$ consumption dynamics and the organization of higher trophic levels (Cloern 1996, Eby \& Crowder 2004, Danielsdottir et al. 2007). An examination of phytoplankton community and species-level responses to excessive urban pollutant loading is critical for developing a mechanistic understanding of the processes that influence ecosystem biotic properties, structure, function, and resilience following major disturbance events (Lotze et al. 2006).

Documentation of the effects of this perturbation on the biota of the Lake Pontchartrain estuary provides insight into coastal ecosystem responses to acute inputs of large volumes of untreated urban wastewater effluent. The purpose of this study was to quantify the response and recovery of the phytoplankton community in Lake Pontchartrain. Our working hypothesis was that effluent inputs would result in significant, sustained changes in phytoplankton biomass, group diversity, and group evenness for several months after hurricane passage. The collective results were then used to assess how the ecosystem responded and determine if and when the system returned to relatively stable conditions.

\section{MATERIALS AND METHODS}

Hurricane Katrina chronology. On 29 August 2005, Hurricane Katrina made landfall along the US Gulf Coast near the Mississippi/Louisiana border as a Category 3 hurricane with sustained winds of $54 \mathrm{~m} \mathrm{~s}^{-1}$. The storm center passed $35 \mathrm{~km}$ east of $\mathrm{New}$ Orleans, Louisiana, producing a surge of 4.6 to $5.8 \mathrm{~m}$ in Lake Pontchartrain that resulted in levee breaches along the Industrial Canal, London Avenue, and 17th Street canals. Nearly $80 \%$ of the city of New Orleans was flooded to depths of up to $6 \mathrm{~m}$ with water supplied from Lake Pontchartrain (Pardue et al. 2005). By 3 September 2005, the US Army Corps of Engineers (USACE) had established temporary stations to pump untreated flood wastewater into adjacent canals with subsequent discharge back into Lake Pontchartrain. Although most of the floodwater had been removed from the city by 16 September 2005, the passage of Hurricane Rita (24 September 2005, 26 d after Katrina) resulted in some additional flooding (Van Metre et al.
2006). On 11 October 2005 (43 d after Katrina), the USACE reported that all floodwaters were removed from the city and discontinued storm-related pumping activities.

Although estimates vary, as much as $852 \times 10^{6} \mathrm{~m}^{3}$ of floodwater, representing ca. 5 to $10 \%$ of the water volume of Lake Pontchartrain, was pumped from the city and back into the lake (Sinigalliano et al. 2007, Dortch et al. 2008). This de-watering process resulted in pointsource discharges of large volumes of untreated wastewater with high concentrations of a variety of organic and inorganic pollutants, pathogens, and nutrients (Pardue et al. 2005, Stoeckel et al. 2005, Hou et al. 2006, Presley et al. 2006, Van Metre et al. 2006).

Study site. Lake Pontchartrain $\left(30.30^{\circ} \mathrm{N}, 90.27^{\circ} \mathrm{W}\right)$ is located in southern Louisiana with the city of $\mathrm{New}$ Orleans along the southern shoreline (Fig. 1). This oligohaline estuary has an average depth of $3.7 \mathrm{~m}$, a salinity range from 0 to 8 (mean $=3.9$ ), and a surface area of $1630 \mathrm{~km}^{2}$ (Bianchi \& Argyrou 1997, O'Connell et al. 2004, Poirrier et al. 2008). The largest freshwater inputs are the Amite, Tickfaw, and Tangipahoa Rivers, and discharges vary seasonally (Xu \& Wu 2006). Although many pumping stations were established following the levee breaches, the primary outfall for hurricane floodwater effluent into Lake Pontchartrain was the 17th Street Canal outfall (Metairie pumping station; $30.024^{\circ} \mathrm{N}, 90.122^{\circ} \mathrm{W}$; Dortch et al. 2008). Presley et al. (2006) reported that floodwater salinities at the outfall ranged from 0.1 to 3.3 and the concentrations of ammonium $\left(\mathrm{NH}_{4}\right)$ and reactive phosphorus $\left(\mathrm{PO}_{4}\right)$ ranged from 30.6 to 64.1 and 11.0 to $53.3 \mu \mathrm{mol} \mathrm{l}^{-1}$, respectively.

Sampling. Water samples were collected at 27 locations within a $12 \mathrm{~km}$ radius from the entrance to the

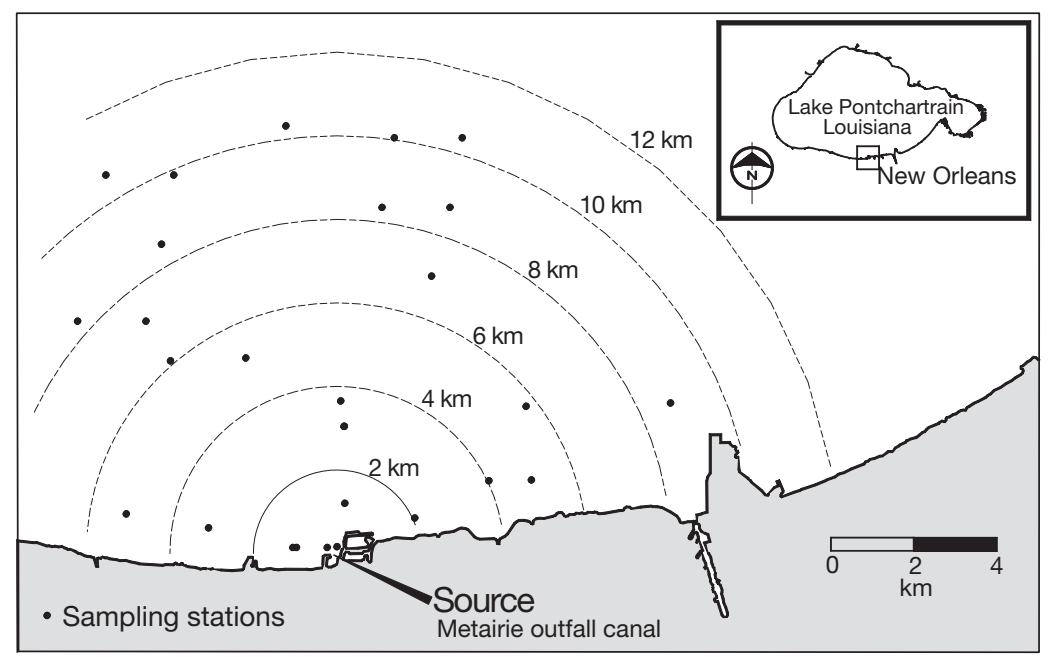

Fig. 1. Study area and sampling stations in Lake Pontchartrain. Source indicates the location of effluent discharge of city floodwater at the 17th Street Canal outfall (Metairie Outfall Canal) 
17th Street Canal outfall. Field sampling was initiated on 15 September 2005 and continued at weekly to biweekly intervals through 12 December 2005 (17 to $105 \mathrm{~d}$ after Hurricane Katrina). The timing of events, sampling dates, and sample sizes are summarized in Table 1. Salinity, temperature, $\mathrm{pH}$, and dissolved oxygen were recorded for each sample using a Seabird Electronics SBE-16plus with an SBE 43 DO sensor (data reported by Hou et al. 2006). Duplicate discrete water samples for phytoplankton pigment analysis were taken from just below the surface at each sampling site using $120 \mathrm{ml}$ sterile specimen cups, stored on ice, and processed within $6 \mathrm{~h}$ of collection. Aliquots of water $(100 \mathrm{ml})$ were filtered under $<50 \mathrm{kPa}$ vacuum onto $4.7 \mathrm{~cm}$ diameter Whatman GF/F filters, which were immediately frozen and stored at $-80^{\circ} \mathrm{C}$.

Phytoplankton samples for microscopic examinations were collected at nearly biweekly intervals (9 dates) from 7 random locations within the study area. For each sample, 6 consecutive vertical net hauls (10 $\mu \mathrm{m}$ mesh, $15 \mathrm{~cm}$ diameter mouth) were obtained from a depth of $2 \mathrm{~m}$ to the surface and preserved in $0.5 \%$ unbuffered glutaraldehyde. Wet mounts for qualitative observations were made from $300 \mu \mathrm{l}$ of the preserved sample and examined with a Nikon Eclipse E600 microscope equipped with brightfield and differential interference contrast (100 to 1000× magnification). Samples were cleaned for diatom identifications in gently boiling ca. $30 \%$ hydrogen peroxide and mounted in Naphrax. The dominant taxa were determined for each sample, and in total, 63 samples were examined over the study period.

Table 1. Chronology of events, sampling dates, and sample sizes for this study

\begin{tabular}{|lcccl|}
\hline Date & $\begin{array}{c}\text { Days after } \\
\text { Katrina }\end{array}$ & $\begin{array}{c}\text { No. of } \\
\text { samples }\end{array}$ & $\begin{array}{c}\text { No. of } \\
\text { stations }\end{array}$ & Event \\
\hline 29 Aug 05 & 0 & & & Hurricane Katrina \\
3 Sep 05 & 5 & & & Pumping stations established \\
15 Sep 05 & 17 & 6 & 5 & \\
16 Sep 05 & 18 & 5 & 5 & \\
18 Sep 05 & 20 & 6 & 5 & \\
19 Sep 05 & 21 & 44 & 15 & \\
21 Sep 05 & 23 & 3 & 3 & \\
24 Sep 05 & 26 & & & Hurricane Rita \\
25 Sep 05 & 27 & 4 & 4 & \\
28 Sep 05 & 30 & 24 & 12 & \\
5 Oct 05 & 37 & 3 & 3 & \\
11 Oct 05 & 43 & 52 & 19 & Floodwaters removed from city \\
19 Oct 05 & 51 & 3 & 3 & \\
23 Oct 05 & 55 & 4 & 4 & \\
25 Oct 05 & 57 & 40 & 18 & \\
8 Nov 05 & 71 & 22 & 9 & \\
23 Nov 05 & 86 & 22 & 9 & \\
1 Dec 05 & 94 & 15 & 5 & \\
12 Dec 05 & 105 & 32 & 9 & \\
\hline
\end{tabular}

Photopigment analyses. High performance liquid chromatography (HPLC) was used to determine chemosystematic photosynthetic pigments for phytoplankton. For analyses, filters were lyophilized for $12 \mathrm{~h}$ at $-50^{\circ} \mathrm{C}$, placed in $1.0 \mathrm{ml} 90 \%$ acetone, sonicated, and extracted at $-20^{\circ} \mathrm{C}$ for 18 to $20 \mathrm{~h}$. Filtered extracts $(200 \mu l)$ were injected into a Shimadzu HPLC equipped with a monomeric (Rainin Microsorb-MV, $0.46 \times 10 \mathrm{~cm}$, $3 \mu \mathrm{m}$ ) and a polymeric (Vydac 201TP54, $0.46 \times 25 \mathrm{~cm}$, $5 \mu \mathrm{m}$ ) reverse-phase $\mathrm{C}_{18}$ column in series. A nonlinear binary gradient consisting of the solvents $80 \%$ methanol:20\% $0.50 \mathrm{M}$ ammonium acetate and $80 \%$ methanol:20\% acetone was used for pigment separations (Pinckney et al. 1996). Absorption spectra and chromatograms $(440 \pm 4 \mathrm{~nm})$ were acquired using a Shimadzu SPD-M10av photodiode array detector. Pigment peaks were identified by comparison of retention times and absorption spectra with pure standards (DHI). The synthetic carotenoid $\beta$-apo-8'-carotenal was used as an internal standard.

ChemTax, a matrix factorization program, was used to calculate the absolute abundances of major algal groups from concentrations of chemosystematic photopigment biomarkers (Mackey et al. 1996, 1997, Wright et al. 1996). This program uses a steepest descent algorithm to determine the best fit based on an initial estimate of pigment ratios for algal classes. Input for the program consists of a raw data matrix of photopigment concentrations obtained by HPLC analyses and an initial pigment ratio matrix. The data matrix is subjected to a factor minimization algorithm that calculates a best fit pigment ratio matrix and a final phytoplankton class composition matrix. The relative abundances of different algal groups derived from ChemTax were used to calculate group diversity (ShannonWiener $H^{\prime}$, base e) and Pielou's evenness index $\left(J^{\prime}\right)$ for each sampling date (Primer v. 5.2.9, Primer-E). The ChemTax analysis was limited to cyanobacteria, dinoflagellate, euglenophyte, cryptophyte, chlorophyte, and diatom groups. The initial pigment ratios for ChemTax were derived from published ratios (Schlüter et al. 2000, Lewitus et al. 2005; our Table 2).

\section{RESULTS}

The average salinity in the study area remained relatively constant between 6 and 8 and the water temperature declined from 31 to $12^{\circ} \mathrm{C}$ from mid-September to mid-Decem- 
ber (Fig. 2). Total phytoplankton biomass (as chlorophyll a [chl a]) exhibited a range of 0.29 to $41.94 \mu \mathrm{g}$ chl $a \mathrm{l}^{-1}$ with a median of $2.62(\mathrm{n}=285)$. The ChemTaxfitted ratios for 10 pigments (final ratio matrix) were achieved after 59 iterations with a resulting root mean square error of 0.221 (Table 2). Diatoms achieved the

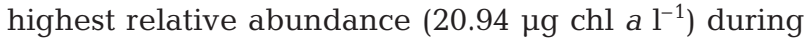
the study period, followed by chlorophytes, cryptophytes, euglenophytes, dinoflagellates, and cyanobacteria, in descending order (Table 3). Qualitative microscopic examination of samples confirmed the presence of all 6 algal groups, and all are historically common groups in this estuary (Bianchi \& Argyrou 1997, J. Wee unpubl. data).

Although the relative abundances of algal groups were variable, diatoms constituted over half of the phytoplankton biomass (51\% of median total chl a) during the study period (Table 3). Based upon qualitative microscopy for 63 net samples, the diatom assemblages were dominated by Skeletonema costatum, various Cyclotella species (e.g. C. striata, C. meneghiniana), and Coscinodiscus sp. Other less frequently encountered taxa observed throughout the samples included Actinoptychus senarius, Ditylum brightwellii, Chaetoceros spp., including C. subtilis var. abnormis, and the pennate taxon Diploneis smithii var. rhombica.

Spatiotemporal contour plots were constructed for total chl a as well as for each of the 6 major algal groups based on the distance ( 0 to $12 \mathrm{~km}$ ) from the discharge source for the wastewater effluent (Fig. 3). Average abundances of phytoplankton groups within the $12 \mathrm{~km}$ radius for each sampling date illustrate the area-integrated response over the study period (Fig. 4). All groups except cyanobacteria exhibited ele-

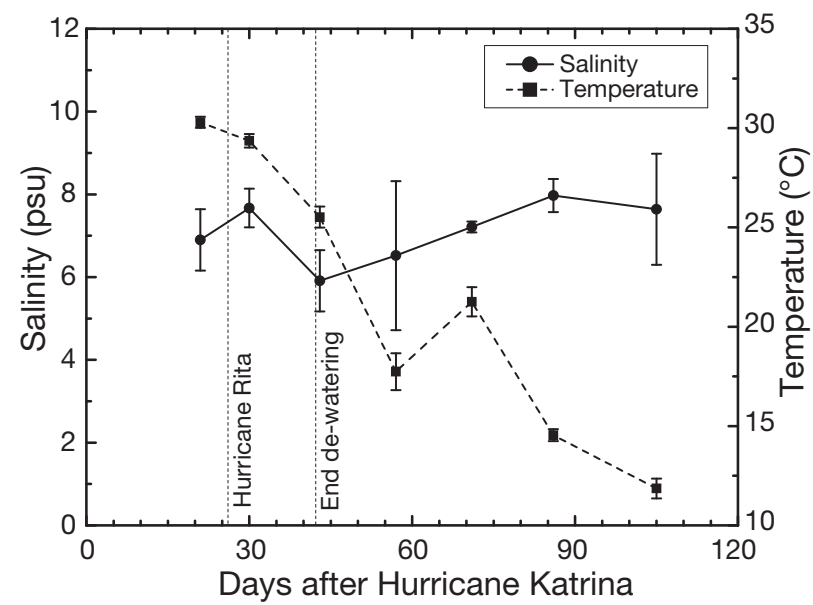

Fig. 2. Salinity and temperature during the study period. Values are the mean \pm 1 SD for 12 locations within the study area sampled on the respective date (data from Hou et al. 2006). Vertical dashed lines indicate the dates for passage of Hurricane Rita (24 September 2005) and termination of floodwater removal activities (11 October 2005)

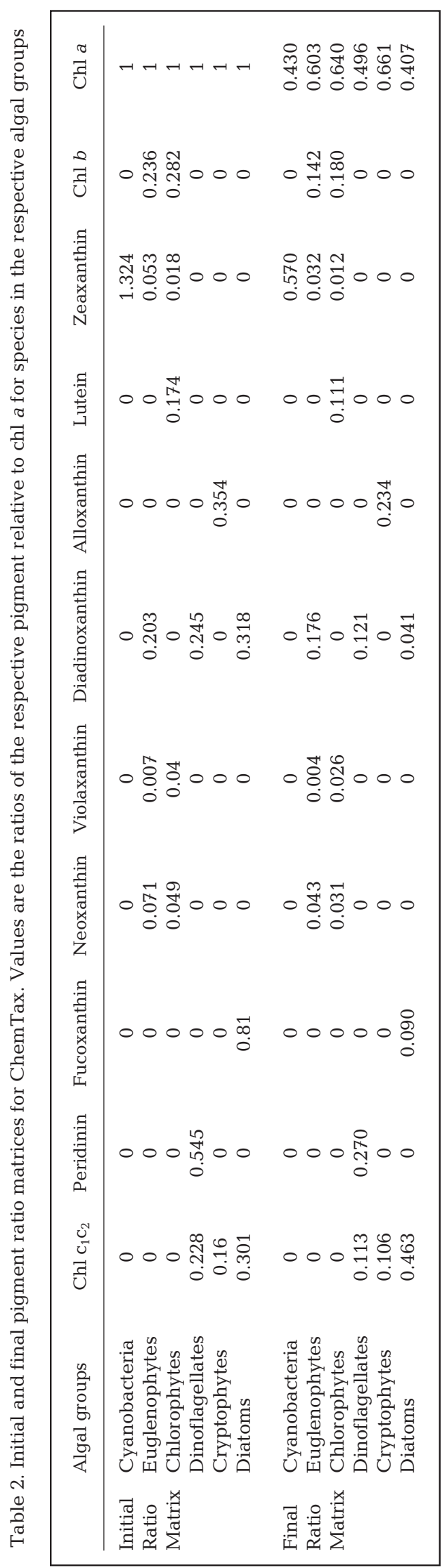


Table 3. Summary statistics for ChemTax-derived relative abundances of algal groups in Lake Pontchartrain during the study period (15 September to 12 December 2005) and the percent contribution of algal groups to the total phytoplankton community. Statistics are based on 285 samples

\begin{tabular}{|c|c|c|c|c|c|c|}
\hline Algal group & $\begin{array}{c}\text { Min. } \\
\left(\mu \mathrm{g} \mathrm{chl} a \mathrm{l}^{-1}\right)\end{array}$ & $\begin{array}{c}\text { Max. } \\
\left(\mu \mathrm{g} \mathrm{chl} a \mathrm{l}^{-1}\right)\end{array}$ & $\begin{array}{c}\text { Median } \\
\left(\mu \mathrm{g} \text { chl } a l^{-1}\right)\end{array}$ & $\begin{array}{c}\text { Range } \\
(\%)\end{array}$ & $\begin{array}{c}\text { Median } \\
(\%)\end{array}$ & $\begin{array}{c}\text { Range }^{\mathrm{a}} \\
(\%)\end{array}$ \\
\hline Euglenophytes & 0.00 & 8.42 & 0.01 & $0.0-98$ & 0.4 & \\
\hline Diatoms & 0.00 & 20.94 & 1.15 & $0.0-91$ & 51 & $3.0-22$ \\
\hline Dinoflagellates & 0.00 & 4.17 & 0.15 & $0.0-53$ & 5.5 & \\
\hline Cyanobacteria & 0.00 & 1.38 & 0.29 & $0.0-52$ & 11 & $8.0-62$ \\
\hline Cryptophytes & 0.00 & 9.26 & 0.33 & $0.0-54$ & 14 & $8.0-22$ \\
\hline Chlorophytes & 0.00 & 14.60 & 0.22 & $0.0-57$ & 8.4 & $4.0-13$ \\
\hline Total chl a & 0.29 & 41.94 & 2.62 & & & \\
\hline
\end{tabular}

vated biomass concentrations during the first $23 \mathrm{~d}$ after hurricane passage, with diatoms showing the highest relative biomass. A second bloom of mostly diatoms, chlorophytes, and cryptophytes was detected $30 \mathrm{~d}$ after Hurricane Katrina and 4 d after the passage of Hurricane Rita. Phytoplankton biomass further declined after the de-watering operations ended, and remained relatively low $\left(<5 \mu \mathrm{g} \mathrm{chl} \mathrm{a} \mathrm{l}^{-1}\right)$ for the duration of the study period. A small, localized bloom of diatoms, cryptophytes, and dinoflagellates occurred $71 \mathrm{~d}$ after Katrina, but the higher concentrations were limited to a small area near the 17th Street Canal outfall. This bloom followed a period of sustained rainfall and was likely associated with rainfall drainage of nutrient-enriched runoff from the city. In summary, phytoplankton blooms were limited to a $40 \mathrm{~d}$ period following Hurricane Katrina, after which levels remained low and relatively constant.

Phytoplankton abundances derived from ChemTax were used to calculate diversity and evenness for each sample, and a mean and standard deviation for all samples was determined for each sampling date (Fig. 5). Group diversity was significantly different between dates (1-way ANOVA, $F_{6,175}=21.07$, power $=$ 1.00, p < 0.001). A Dunnett's T3 test was used for a posteriori multiple comparisons of means due to heteroscedastic error variances (Levene's test, $\mathrm{p}<0.001$ ) and revealed 2 homogeneous groups (Fig. 5), suggesting a significant reduction in diversity between $28 \mathrm{Sep}-$ tember and 11 October (30 to $43 \mathrm{~d}$ after Katrina; $\mathrm{p}<$ 0.01). Although group evenness differed significantly between sampling dates (1-way ANOVA, $F_{6,175}=$ 3.597, power $=0.95, \mathrm{p}=0.002$ ), multiple comparisons of means indicated 2 homogeneous groups (Bonferroni, $\mathrm{p}<0.01$ ) and suggests that algal group evenness was relatively constant from September through December (Fig. 5). Overall, group diversity declined 1 mo after Katrina and remained unchanged until the end of the study period, whereas group evenness showed little change following the hurricanes.

\section{DISCUSSION}

Historically, salinities in Lake Pontchartrain range from 0 to 8 (Bianchi \& Argyrou 1997). Floodwater salinities averaged 5.6 (Presley et al. 2006, Dortch et al. 2008), while lake salinities following Hurricane Katrina varied from 6 to 8 and were within the range of values (4 to 11 ) reported by others for the same time period (Sinigalliano et al. 2007, Dortch et al. 2008, Poirrier et al. 2008). De-watering of the city resulted in an estimated floodwater volume of 540 to $852 \times 10^{6} \mathrm{~m}^{3}$, representing as much as $10 \%$ of the lake volume (Sinigalliano et al. 2007, Dortch et al. 2008). These results suggest that much of the wastewater pumped out of New Orleans during de-watering operations originated as floodwater from Lake Pontchartrain, and inputs of rainfall and runoff as well as salinity changes in the lake after the hurricanes were minimal. Hydrodynamic models of effluent dispersion during pumping operations showed that the discharge plume of elevated water-soluble pollutant and fecal coliform bacteria concentrations was limited to a 5 to $10 \mathrm{~km}$ band offshore from the outfalls and overlapped our study area (Dortch et al. 2008). The spatiotemporal distributions of phytoplankton abundance documented in the present study are consistent with these model predictions and suggest that blooms resulting from de-watering operations were restricted to effluent plumes in the vicinity of the outfalls.

Historically, nitrogen has been the growth-limiting nutrient for phytoplankton in Lake Pontchartrain, and the lake has experienced significant N-loading in recent years (Bianchi \& Argyrou 1997, Turner et al. 2002). In studies prior to Hurricane Katrina, nutrient concentrations in Lake Pontchartrain were reportedly 3.3 to $8.3 \mu \mathrm{mol}{ }^{-1}$ for $\mathrm{NH}_{4}{ }^{+}$and 1.2 to $2.0 \mu \mathrm{mol} \mathrm{l}{ }^{-1}$ for $\mathrm{PO}_{4}{ }^{-3}$ (Bianchi \& Argyrou 1997). However, in floodwaters following the hurricane, the concentrations of $\mathrm{NH}_{4}{ }^{+}$and $\mathrm{PO}_{4}{ }^{-3}$ ranged from 30.6 to 64.1 and 11.0 to $53.3 \mu \mathrm{mol} \mathrm{l}^{-1}$, respectively; these values are higher 


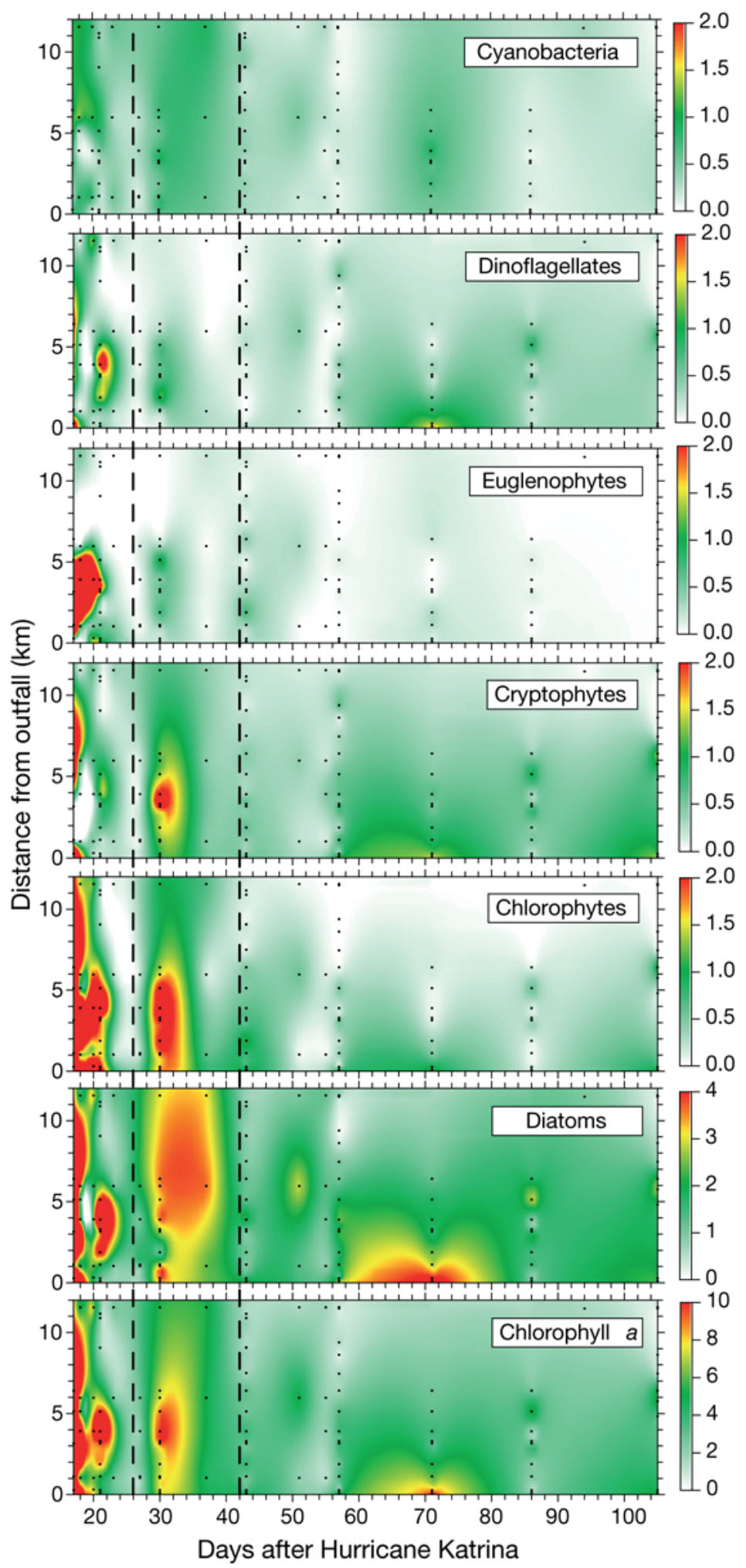

Fig. 3. Spatiotemporal contour plots for the ChemTax-derived concentrations of respective algal groups (cyanobacteria, dinoflagellates, euglenophytes, cryptophytes, chlorophytes, and diatoms) as well as the total phytoplankton concentrations ( $\mathrm{chl}$ a). Vertical dashed lines indicate the dates for passage of Hurricane Rita (24 September 2005) and termination of floodwater removal activities (11 October 2005) than historical levels by factors of 8 and 30, respectively (Presley et al. 2006). Thus, effluent discharged into the lake was enriched with a traditionally limiting nutrient for this system. As expected, nutrient inputs into this $\mathrm{N}$-limited estuary resulted in phytoplankton blooms. Phytoplankton biomass was elevated (as high as $42 \mu \mathrm{g}$ chl $a^{-1}$ ) and exhibited bloom concentrations in the outfall area soon after the passage of Hurricanes Katrina and Rita. On 11 October 2005 (43 d after Katrina), biomass had declined to $<4 \mu \mathrm{g} \mathrm{chl} \mathrm{a} \mathrm{l}^{-1}$ over much of the study area, suggesting that nutrients were quickly depleted following the termination of pumping activities. Similarly, Sinigalliano et al. (2007) reported values of 0.8 to

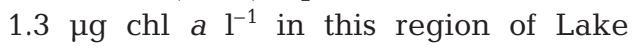
Pontchartain on 8 November 2005 (71 d after Katrina). The small, primarily diatom, bloom at the mouth of the 17 th Street Canal on Day 71 was associated with city rainfall drainage and further illustrates the sensitivity and rapid response to nutrient input by phytoplankton in Lake Pontchartrain.

The determination of pre-hurricane levels of phytoplankton biomass and community composition for Lake Pontchartrain is difficult due to the paucity of long-term data and the fact that there were no baseline measurements immediately preceding the storm. However, several studies have documented commonly occurring seasonal blooms of cyanobacteria (Darnell 1961, Bianchi \& Argyrou 1997, Turner et al. 2004). In a study conducted from May 1995 to May 1996, Bianchi \& Argyrou (1997) reported a chl a range from 0.3 to $6.9{\mu \mathrm{g} \mathrm{l}^{-1}}^{-1}$ and a mean $( \pm 1 \mathrm{SD})$ of $2.3 \pm 0.9 \mu \mathrm{g} \mathrm{l}^{-1}$, which is comparable to the median value found in the present study $\left(2.62 \mu \mathrm{g} \mathrm{l}^{-1}\right)$. In 1997, chl a concentrations in Lake Pontchartrain ranged from 5 to $20 \mu \mathrm{g} \mathrm{l}^{-1}$ (Turner et al. 2004). Several hurricanes (Ivan, Cindy, Dennis, Katrina) that affected Gulf of Mexico estuaries in 2004 and 2005 stimulated phytoplankton blooms in Florida and Alabama estuaries in the weeks following the hurricanes (Hagy et al. 2006, Cebrian et al. 2008). However, water quality conditions were within the range of historical variability for these estuaries within days after the hurricane. Both Hagy et al. (2006) and Cebrian et al. 


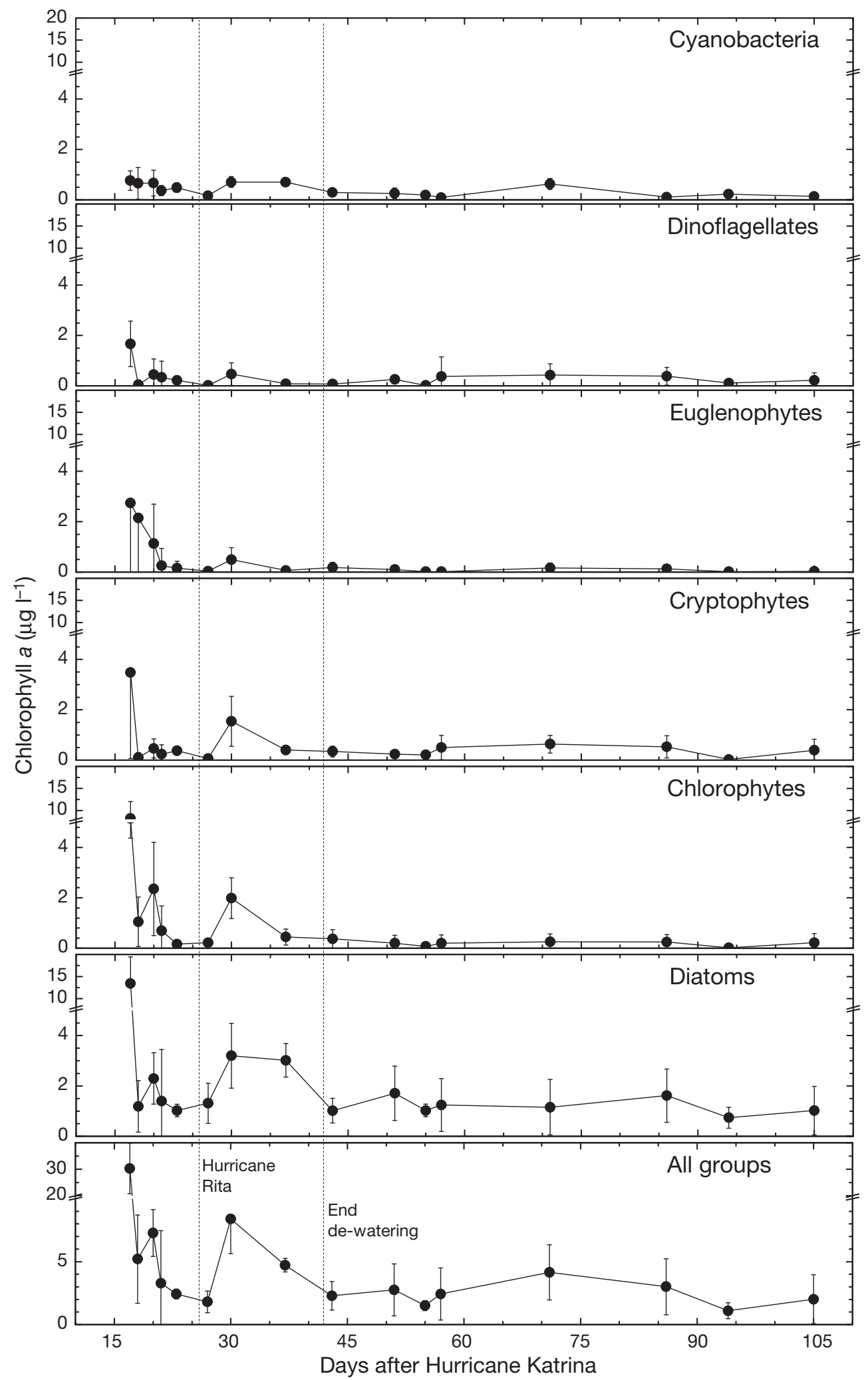

Fig. 4. Area integrated concentrations for the ChemTax-derived algal groups. Values are the mean \pm 1 SD for all samples collected in the study area on the respective date. Note the break points on the $y$-axes. The concentrations of individual groups are plotted using the same vertical scale to illustrate relative abundances. Vertical dashed lines indicate the dates for passage of Hurricane Rita (24 September 2005) and termination of floodwater removal activities (11 October 2005) 


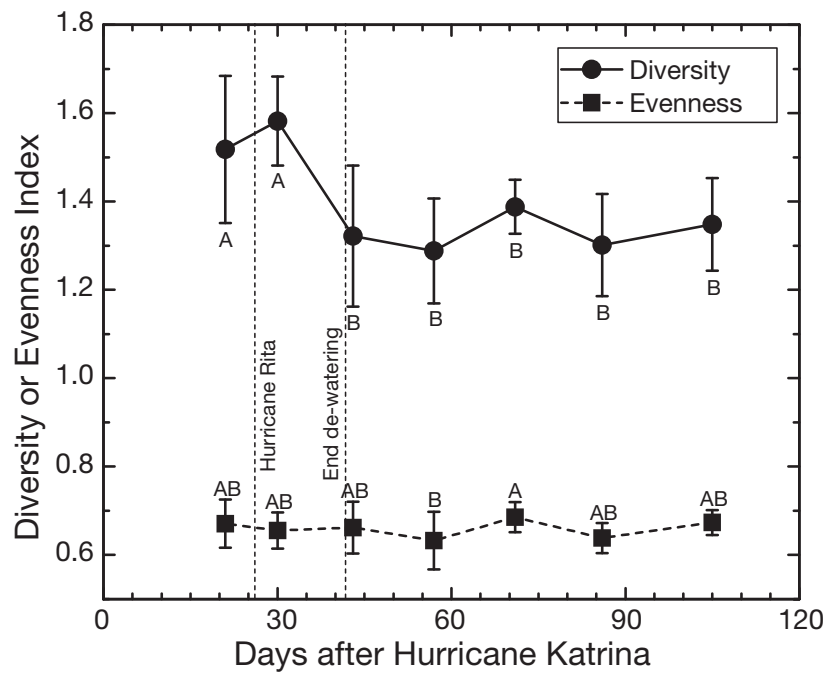

Fig. 5. Phytoplankton group diversity and evenness. Values are the mean \pm 1 SD for all locations sampled on the respective date. The results of post hoc means comparisons are indicated by letters. Points labeled with identical letters (A, B, or AB) are not significantly different $(p>0.05)$. Vertical dashed lines indicate the dates for passage of Hurricane Rita (24 September 2005) and termination of floodwater removal activities (11 October 2005)

(2008) concluded that water quality and phytoplankton productivity in their respective estuaries were quite resilient with respect to hurricane effects.

The only published information on pre-hurricane phytoplankton community composition in Lake Pontchartrain (Bianchi \& Argyrou 1997) reported relative abundance ranges similar to the present study (Table 3). However, diatoms were the only group for which the median abundance in this study $(51 \%)$ fell outside of the range ( 3 to $22 \%$ ) listed by Bianchi \& Argyrou (1997). Photopigment and microscopic observations indicate that fucoxanthin-containing dinoflagellates were not present and likely did not affect ChemTaxderived estimates of diatom abundance in the present study. Therefore, our estimates of high diatom abundance likely reflect true and accurate changes in community composition. Under nutrient-replete conditions, diatoms typically have higher growth rates than other species (Eppley 1972, Banse 1982). The relatively rapid nitrogen uptake rates for diatoms confer a competitive advantage over other groups such as cyanobacteria and chlorophytes and may explain the observed community response in Lake Pontchartrain (Tilman et al. 1986). Nutrient inputs following Katrina seem to have preferentially promoted diatom blooms that declined in magnitude as active wastewater pumping during the de-watering process was discontinued. Many diatoms have been characterized as 'opportunistic' species capable of rapid growth rate compared to other algal groups (Kilham \& Kilham
1980, Banse 1982, MacIntyre et al. 2002). A rapid growth rate in combination with higher nutrient uptake rates may have fostered the growth of diatoms under the high nutrient loading conditions in the effluent plume. The diatom response in the present study mirrors the response of phytoplankton to nutrient pulsing in other Gulf of Mexico estuaries (Pennock et al. 1999, Örnólfsdóttir et al. 2004).

The importance of functional group diversity for ecosystem processes has been demonstrated for a variety of ecosystems (Tilman et al. 1997), and many other studies have shown that the functional characteristics of species are more important than the number of species for ecosystem processes (Hooper \& Vitousek 1997, Bolam et al. 2002, Ives \& Carpenter 2007). Assuming that an increase in functional diversity promotes ecosystem productivity, stability, homeostasis, and resilience to perturbations, phytoplankton group diversity (PGD) may indicate relative changes in ecosystem 'health' (Cloern \& Dufford 2005, Flombaum \& Sala 2008). Evenness is a measure of the relative abundances of functional groups and is maximal when all groups have equal abundances in the community.

In this study, PGD, which was based on the relative abundances of 6 major algal groups, ranged from 1.6 to 1.3 and declined significantly in the weeks following Katrina, whereas evenness was relatively constant. The Shannon-Wiener group diversity index used in this study incorporates both richness (number of groups) and evenness (abundances within groups). The decrease in PGD following de-watering operations can be attributed primarily to a reduction in the number of algal groups present at any given time (richness), while the algal abundances within each of the groups (evenness) was relatively constant. The overall decline in phytoplankton biomass likely resulted from the removal of nutrient loading from wastewater inputs, while the almost constant evenness index suggests minimal changes in the relative abundances of the 6 phytoplankton groups. Therefore, the overall phytoplankton community response was an increase in the abundance of all groups during pumping operations while maintaining the relative proportions of group abundances. The constancy in diversity and evenness measures after the hurricane suggests a stable system that quickly returned to a steady-state condition following this major perturbation event. Shortterm ( 30 to $45 \mathrm{~d}$ ) increases in PGD following hurricanes have been documented in the Neuse River Estuary, possibly due to nutrient enrichment and/or salinity gradients that support growth of both marine and freshwater species (Paerl et al. 1998, 2001, 2006). Nutrient inputs following hurricanes may increase diversity and enhance productivity for a few weeks, but usually do not result in a long-term alteration of 
community composition (Greening et al. 2006, Cebrian et al. 2008).

In summary, phytoplankton exhibited a short-term bloom response to wastewater inputs near the pumping station outfall. In the weeks following Katrina, phytoplankton community composition was initially dominated by diatoms, but the diversity and biomass of all algal groups declined and remained relatively constant through December. Phytoplankton concentrations returned to relatively constant low levels by early October 2005. Other than a moderate bloom during pumping operations, Hurricanes Katrina and Rita had very little effect on phytoplankton in Lake Pontchartrain. However, the sedimentation of pollutants and subsequent resuspension by future storms may have negative effects on flora and fauna in the lake (Miller \& McKee 2004, Jeng et al. 2005).

Acknowledgements. Funding for this project was provided by the Coastal Resiliency Information Systems Initiative for the Southeast (CRISIS) Program at the University of South Carolina (J.L.P. and J.L.W.) and the NSF grant OCE-0554674 (A.H.). K. Carman facilitated the collaborations that made this project possible. We thank M. Jelloe, M. Coggins, D. Johnson, K. Vogel, and L. Wyrobeck for assistance with HPLC analyses. This is publication 1579 from the Belle W. Baruch Institute for Marine Biology and Coastal Research.

\section{LITERATURE CITED}

Banse K (1982) Cell volumes, maximal growth rates of unicellular algae and ciliates, and the role of ciliates in the marine pelagial. Limnol Oceanogr 27:1059-1071

Bianchi TS, Argyrou ME (1997) Temporal and spatial dynamics of particulate organic carbon in the Lake Pontchartrain Estuary, Southeast Louisiana, USA. Estuar Coast Shelf Sci 45:557-569

Bolam S, Fernandes TF, Huxham M (2002) Diversity, biomass, and ecosystem processes in the marine benthos. Ecol Monogr 72:599-615

- Cebrian J, Foster CD, Plutchak R, Sheehan KL and others (2008) The impact of Hurricane Ivan on the primary productivity and metabolism of marsh tidal creeks in the NorthCentral Gulf of Mexico. Aquat Ecol 42:391-404

> Cloern J (1996) Phytoplankton bloom dynamics in coastal ecosystems: a review with some general lessons from sustained investigation of San Francisco Bay, California. Rev Geophys 34:127-168

- Cloern JE, Dufford R (2005) Phytoplankton community ecology: principles applied in San Francisco Bay. Mar Ecol Prog Ser 285:11-28

> Danielsdottir MG, Brett MT, Arhonditsis GB (2007) Phytoplankton food quality control of planktonic food web processes. Hydrobiologia 589:29-41

Darnell RM (1961) Trophic spectrum of an estuarine community, based on studies of Lake Pontchartrain, Louisiana. Ecology 42:553-568

> Dortch MS, Zakikhani M, Kim SC, Steevens JA (2008) Modeling water and sediment contamination of Lake Pontchartrain following pump-out of Hurricane Katrina floodwater. J Environ Manag 87:429-442
Eby L, Crowder LB (2004) Effects of hypoxic disturbances on an estuarine nekton assemblage across multiple scales. Estuaries 27:342-351

Eppley RW (1972) Temperature and phytoplankton growth in the sea. Fish Bull (Wash D C) 70:1063-1085

Flombaum P, Sala OE (2008) Higher effect of plant species diversity on productivity in natural than artificial ecosystems. Proc Natl Acad Sci USA 105:6087-6090

Greening H, Doering P, Corbett C (2006) Hurricane impacts on coastal ecosystems. Estuar Coasts 29:877-879

Hagy JD, Lehrter JC, Murrell MC (2006) Effects of Hurricane Ivan on water quality in Pensacola Bay, Florida. Estuar Coasts 29:919-925

> Hooper DU, Vitousek PM (1997) The effects of plant composition and diversity on ecosystem processes. Science 277: 1302-1305

Hou A, Laws EA, Gambrell RP, Bae HS and others (2006) Pathogen indicator microbes and heavy metals in Lake Pontchartrain following Hurricane Katrina. Environ Sci Technol 40:5904-5910

Ives AR, Carpenter SR (2007) Stability and diversity of ecosystems. Science 317:58-61

> Jeng HAC, Englande AJ, Bakeer RM, Bradford HB (2005) Impact of urban stormwater runoff on estuarine environmental quality. Estuar Coast Shelf Sci 63:513-526

Kilham P, Kilham S (1980) The evolutionary ecology of phytoplankton. In: Morris I (ed) The physiological ecology of phytoplankton. Univ Calif Press, Berkeley, CA, p 571-597

- Lewitus AJ, White DL, Tymowski RG, Geesey ME, Hymel SN, Noble PA (2005) Adapting the CHEMTAX method for assessing phytoplankton taxonomic composition in Southeastern U.S. estuaries. Estuaries 28:160-172

Lotze HK, Lenihan HS, Bourque BJ, Bradbury RH and others (2006) Depletion, degradation, and recovery potential of estuaries and coastal seas. Science 312:1806-1809

MacIntyre H, Kana T, Anning T, Geider R (2002) Photoacclimation of photosynthesis irradiance response curves and photosynthetic pigments in microalgae and cyanobacteria. J Phycol 38:17-38

Mackey MD, Mackey DJ, Higgins HW, Wright SW (1996) CHEMTAX - a program for estimating class abundances from chemical markers: application to HPLC measurements of phytoplankton. Mar Ecol Prog Ser 144:265-283

Mackey MD, Higgins HW, Mackey DJ, Wright SW (1997) CHEMTAX user's manual: a program for estimating class abundances from chemical markers-application to HPLC measurements of phytoplankton pigments. CSIRO Marine Laboratories Report 229, Hobart

Miller RL, McKee BA (2004) Using MODIS Terra $250 \mathrm{~m}$ imagery to map concentrations of total suspended matter in coastal waters. Remote Sens Environ 93:259-266

O'Connell MT, Cashner RC, Schieble CS (2004) Fish assemblage stability over fifty years in the Lake Pontchartrain estuary; comparisons among habitats using canonical correspondence analysis. Estuaries 27:807-817

Örnólfsdóttir EB, Lumsden SE, Pinckney JL (2004) Phytoplankton community growth-rate response to nutrient pulses in a shallow turbid estuary, Galveston Bay, Texas. J Plankton Res 26:325-339

Paerl HW, Pinckney JL, Fear JM, Peierls BL (1998) Ecosystem responses to internal and watershed organic matter loading: consequences for hypoxia in the eutrophying Neuse River Estuary, North Carolina, USA. Mar Ecol Prog Ser 166:17-25

Paerl HW, Bales JD, Ausley LW, Buzzelli CP and others (2001) Ecosystem impacts of three sequential hurricanes (Dennis, Floyd, and Irene) on the United States' largest lagoonal 
estuary, Pamlico Sound, NC. Proc Natl Acad Sci USA 98: 5655-5660

Paerl HW, Valdes LM, Joyner AR, Peierls BL and others (2006) Ecological response to hurricane events in the Pamlico Sound system, North Carolina, and implications for assessment and management in a regime of increased frequency. Estuaries Coasts 29:1033-1045

Pardue JH, Moe WM, McInnis D, Thibodeaux LJ and others (2005) Chemical and microbiological parameters in New Orleans floodwater following Hurricane Katrina. Environ Sci Technol 39:8591-8599

Pennock JR, Boyer JN, Herrera-Silveira JA, Iverson RL, Whitledge TE, Mortazavi B, Comin FA (1999) Nutrient behavior and phytoplankton production in Gulf of Mexico estuaries. In: Bianchi TS, Pennock JR, Twilley RR (eds), Biogeochemistry of Gulf of Mexico estuaries. John Wiley \& Sons, Chichester, p 109-162

Pinckney JL, Millie DF, Howe KE, Paerl HW, Hurley J (1996) Flow scintillation counting of ${ }^{14} \mathrm{C}$-labeled microalgal photosynthetic pigments. J Plankton Res 18:1867-1880

Poirrier MA, Rodriguez del Rey Z, Spalding EA (2008) Acute disturbance of Lake Pontchartrain benthic communities by Hurricane Katrina. Estuaries Coasts 31:1221-1228

Presley SM, Rainwater TR, Austin GP, Platt SG and others (2006) Assessment of pathogens and toxicants in New Orleans, LA following Hurricane Katrina. Environ Sci Technol 40:468-474

Riedel G, Sanders JG, Breitburg DL (2003) Seasonal variability in response of estuarine phytoplankton communities to stress: linkages between toxic trace elements and nutrient enrichment. Estuaries 26:323-338

Roelke DL, Cifuentes LA, Eldridge PM (1997) Nutrient and phytoplankton dynamics in a sewage-impacted gulf coast estuary: a field test of the PEG-Model and equilibrium resource competition theory. Estuaries 20:725-742

Schlüter L, Møhlenberg F, Havskum H, Larsen S (2000) The use of phytoplankton pigments for identifying and quantifying phytoplankton groups in coastal areas: testing the

Editorial responsibility: Just Cebrian,

Dauphin Island, Alabama, USA influence of light and nutrients on pigment/chlorophyll $a$ ratios. Mar Ecol Prog Ser 192:49-63

Sinigalliano CD, Gidley ML, Shibata T, Whitman D and others (2007) Impacts of Hurricanes Katrina and Rita on the microbial landscape of the New Orleans area. Proc Natl Acad Sci USA 104:9029-9034

Stoeckel DM, Buson RN, Demcheck DK, Skrobialowski SC and others (2005) Bacteriological water quality in the Lake Pontchartrain Basin, Louisiana, following Hurricanes Katrina and Rita, September 2005. US Geological Survey, Data Series 143

Tilman D, Kiesling R, Sterner R, Kilham SS, Johnson FA (1986) Green, bluegreen and diatom algae: taxonomic differences in competitive ability for phosphorus, silicon and nitrogen. Arch Hydrobiol 106:473-485

> Tilman D, Knops J, Wedin D, Reich P, Ritchie M, Siemann E (1997) The influence of functional diversity and composition on ecosystem processes. Science 277:1300-1302

Turner RE, Dortch Q, Justiç D, Swenson EM (2002) Nitrogen loading into an urban estuary: Lake Pontchartrain (Louisiana, U.S.A.). Hydrobiologia 487:137-152

Turner RE, Dortch Q, Rabalais NN (2004) Inorganic nitrogen transformations at high loading rates in an oligohaline estuary. Hydrobiologia 68:411-422

> Van Metre PC, Horowitz AJ, Mahler BJ, Foreman WT and others (2006) Effects of Hurricanes Katrina and Rita on the chemistry of bottom sediments in Lake Pontchartrain, Louisiana, USA. Environ Sci Technol 40:6894-6902

> Wright SW, Thomas DP, Marchant HJ, Higgins HW, Mackey MD, Mackey DJ (1996) Analysis of phytoplankton of the Australian sector of the Southern Ocean: comparisons of microscopy and size frequency data with interpretations of pigment HPLC data using the 'CHEMTAX' matrix factorisation program. Mar Ecol Prog Ser 144:285-298

Xu YJ, Wu K (2006) Seasonality and interannual variability of freshwater inflow to a large oligohaline estuary in the northern Gulf of Mexico. Estuar Coast Shelf Sci 68: $619-626$

Submitted: October 6, 2008; Accepted: April 28, 2009

Proofs received from author(s): June 26, 2009 